\title{
Cultural Conceptualization of Women in Igbo Proverbs
}

\author{
Ngozi U. Emeka-Nwobia \& Roseline I. Ndimele \\ http://dx.doi./org/10.4314/ujah.v20i1.8
}

\section{Abstract}

There is a popular narrative that women are the weaker vessels and depend on men for confirmation of their thoughts and actions. This narrative is expressed linguistically through the pejorative and diminutive portrayal of women in Igbo proverbs. Proverbs are powerful and potent vehicle for culture dissemination from one generation to the other. The functionality and cultural essence therefore transcends generational sayings and performances. Proverbs are metaphorical statements and reflection of the people's cultures, indigenous knowledge, cosmology, value, spirituality and essence. They provide channels for intergenerational transfers from old to young members of the society. Among the Igbo of the south eastern Nigeria, it is said to be the oil with which words are eaten. Applying Lakoff's concept of Women language and Critical discourse Analytical theory, this paper examines the representation of women in Igbo proverb. The objective is to examine the nexus between language, gender and culture. It specifically analyses the traditions, views, perceptions and roles of women in traditional and contemporary Igbo society. Forty five Igbo proverbs about women were selected from both written and oral sources. These include Igbo proverbs that literarily mentioned women (old women - agadi nwaanyi, young woman/lady - nwaagbogho, wife - nwunye and the woman's body) and explored its portrayal without much attention to the contextualised meaning which may vary according to usage at different context, though being one of the fluidities of proverbs. Findings reveal that in spite of the changing role of women in Igbo society, the cultural interpretations/conations attached to these 
proverbs are still untainted. Women are still stereotyped as subservient, weak, vulnerable and evil using proverbs. This cultural representation extols hegemonic masculinity and feminity.

Key words: Igbo Language, Culture, Proverb, Igbo Women

\section{Introduction}

The paper examines the nexus between language, gender and culture. Specifically, it explores the construction of women and womanhood in Igbo proverb. The intertwined relationship between language and culture have attracted quite a number of scholarly attention especially on explorations of the role of language in the expression, construction and deconstruction of gender identities (cf. Cameroon 2005, Wardaugh 2006 , Diabah and Amfo 2015). This paper is a modest contribution to the study of language, culture and gender in Igbo society. It examines the culture, traditions, perceptions and representation of women in this witty assemblage of the people's wisdom - proverb.

Literature is replete with studies on proverb from African perspective (eg, Yankah 2012, Asimeng-Boahene, 2009, 2010, 2013; Awedoba, 2000; Yitah, 2007, 2011). Quite a number have also examined proverbs from gendered lenses (cf. Diabah and Amfo 2014, Asimeng-Boahene, 2013; Oduyoye, 1979, Anderson, 2012, Muwati et al., 2011, Wang, 2012). In Igbo cultural context, quite a number of studies have been carried out on proverbs (cf NwachukwuAgbada 2002, Emenanjo2012, etc). A few others have explored the place of proverb in the construction of female identities (Oha 1998, Onyejekwe 2005, Mmadike 2014, etc) This study is unique in its application of Lakoff's concept of Women language and Critical discourse Analytical theory in the exploration of Igbo gendered proverbs to determine the cultural conceptualisation of a woman and womanhood in the society. 


\section{The Igbo of South-east Nigeria}

The name Igbo (also called the Ibo(s) by the colonialist) refers to both the people (speakers) and their language. The Igbo people live mainly in the southeast of Nigeria, in the states of Abia, Anambra, Ebonyi, Enugu, and Imo, also in parts of Delta and Rivers states. The language is predominantly spoken in these areas as their major languages, and as minor languages in Equatorial Guinea (https://joshuaproject.net/people_groups/12189/EK), Jamaica,( Muller,1993) and every parts of the world where Igbo people are found in their clusters (Emeka-Nwobia, 2019). The language is spoken by over 27 million speakers (Ethnologue, 2018) and the society is predominantly a patriarchal society like most African societies though few societies that make up the larger Igbo society practice matriarchy or a mixture of both.

\section{Overview of Proverbs: The Igbo Example}

Proverbs are sacred metaphorical words imbued with wisdom which provide channels of intergenerational cultural transfer/ transmission of indigenous knowledge, cultural heritage, values, spirituality, cosmology and essence of the people. They are allusive, metaphoric and condensed saying which draws from traditional experiences of the society. As a universal phenomenon, their content and meaning are culture specific and each society defines the appropriateness of their usage.

Among the Igbo people proverbs are the palm oil with which words are eaten (Achebe 1958). Fakoya (2007) notes that in Yoruba context, proverbs are the vehicle of thought, used to extract truth, in obscured and elusive situations. He observed that, "Among the Yorùbá and the Igbo of Nigeria, ....proverbs are the spirit and soul of language use" (p.2). The forgoing portrays the extolled place of proverbs in communicative exchanges by cultural 
conscious members of the Igbo society and African societies in general.

Proverbs play major role in the preservation of Igbo norm and lore. In spite of the intergenerational transfers and transmissions, the content, forms and context of usage remain constant. They provide outlets for inquiries into the peoples' view about life, experience, family structure, governance, belief, kinship structure, moral values, taboos, and the entire essence of the people held over generations. Proverbs are assemblages of wisdom and imbued with didactic functions. Culture versed members of the society, embellish their speeches with proverbs not just for oratory or knowledge display but also for didactic purpose (NwachukwuAgbada, 2002). Children and young adults are socialised and taught societal values, norms, values, indigenous knowledge and the entirety of the people's culture using proverbs. One proverb may elicit humour while another may appear stern, likewise the situational context may bring about change in the meaning and effect of the use of a proverb.

The use of proverb is beyond mere mastery and display of the proverbs but demand knowledge of what constitute appropriateness in situation and context of usage. Most African music, folk lore, in fact, the entirety of African orality are usually embellished with proverbs. Proverbs therefore are reflection of the views of a given society on life phenomenon, thus the essence of this study.

\section{Language and Women's Place}

Quite a number of studies exist on variation in the way men and women speak or being spoken to. Lakoff's 1970s work is a seminal in which she came up with the concept of women's language. She observed that language is an instrument of subjugation of women 
by male members of the society. Lakoff notes that this relegated status of women is evident in the way women speak, expected to speak and the way they are spoken to by other members of the society; Lakoff 1973, p. 45). This has led to the linguistic submerging of women's identity in traditional and in most contemporary societies. Women experience linguistic discrimination on how they are socialized to use the language; and in the way the language is used on them (Lakoff p.45, Mulac et al 2001).

Lakoff further identified ten characteristic features of male versus female conversions in her work titled; Language and Woman's Place. She notes among other things, that women tend to use more intensifier, adjectives and question tags, than men in their conversations. This view is supported by quite a number of scholars like Mulac et al 2001; Poynton 1989) Questions tags are used in order to validate women's view, seek approval or confirmation of their speech and action. This age long stereotyped is however challenged in a study conducted by a team from the Universities of Oxford and Cambridge researchers, which revealed exception this rule. In their study of question-asking behaviour at a large international conference with 2000 attendees, which promoted equality and prohibited any form of discrimination, findings show that male attendees asked $80 \%$ more questions than female attendees. The researchers note that the recognised and ongoing issues of gender inequality may be affecting female scientists' confidence and willingness to speak publicly (Amy Hinsley, William J. Sutherland, and Alison Johnston, 2017). This same view is expressed in Alecia Carter (2018) work, which observes that women ask fewer questions than men in academic conferences and seminars. 
Men's language on the other hand is societal constructed as a language of the superior, powerful and stronger group who hold and wield powers as such there is tendency for other members of the society to learn their language and linguistic behaviour. The reverse is not always the case, with exception of those who oppose the American masculine image like the homosexuals. Lakoff however made exception to the adherence of these rules by men in the academia. According to her, academic men tend to violate these rules because they do not work in the real world but are secured and protected from the search for power and money. They are shielded from the harsh realities of real world. Lakoff sums up her assertion, noting that language is an instrument of subjugation of women by male members of the society.

Language tough may appear subtle, but it has the potentials of hurting or relieving hurt depending on usage. Sometime, it is subtly utilized to conceal obvious or seemingly hash truth. Proverbs are one of the creative genre which provide subtle and opaque representation of every facet of social experience.

\section{Methodology}

Data was collected from oral and documented sources. A total of 50 proverbs relating to women were collected. Some of the proverbs were explicit in the mention of woman 'nwaanyi' or 'mother 'nne'. Others used age differentiation like 'nwaagbogho' 'young woman' or 'agadi nwaanyi'- old woman. The selected proverbs were analysed based on recurring patterns or themes. A total of thirteen categories were identified and used in the analysis. Being speakers of Igbo language, the proverbs collected through oral sources using recorders, were translated by the researchers. However, Igbo language specialists were consulted to verify the denotative and connative meanings of the proverbs. Additional 
information was equally elicited through extensive reading of related literatures on African orality and proverbs.

\section{Construction of Women in Igbo Proverbs}

This section is interested in exploring the nexus between language, gender and culture. Data was analysed based on recurring patterns or themes in the selected proverbs. The proverbs were further put into thirteen identified categories, with four based on positive construction of women and eight based on the negative construction of women.

\section{Positive Construction of Woman in Igbo proverbs}

This will be examined under the following sub-categorisation:

\section{i. Mother and Motherhood:}

Proverbs in this category reflect the cultural and traditional role of mothers/ women in Igbo culture. The concept of motherhood is very important in most African culture. A mother is seen as a loving life giver/source of life, who has all it takes to bring another life to existence through her body. She is constructed as a care giver and is naturally endowed to nurture a child from the first day of life care till adulthood. Her roles include bearing and raising children, teaching and living exemplary life. She is constructed as a teacher and role model (especially to the girl child). Her motherhood role places demand on her to live as a manager, equipped with managerial skill of always providing for the family and even saving for the raining days irrespective of the availability of resources at her disposal. The society expects her to live a sacrificial life; she can afford to cook with fish without having a share of it at meal time. She is expected to sacrifice a portion if not all of her meal for 
other members of the family and sometimes neighbours. A mother is reflected as the epicentre of every happening in the family. She is portrayed as a healer whose body possesses the warmth and in fact magical wand to heal every ailment. Thus this proverb;

1. Ahu nne bu ogwu

The body of a mother is medicinal/therapeutic

In Igbo culture, a mother receives blames for any failures or breakdown and sometimes shares the glory (though remotely) with a man over successes recorded in the family. The following proverbs capture the motherhood experiences and societal expectations of an Igbo woman;

2. O nweghi onye na-asị na ofe nne ya siri dị njo

No one says that the mother's food is not sweet

3. Nwata ga-eji aguru ehihie mara ihe onwu nne bu

A child uses afternoon hunger to know the meaning of the death of a mother)

4. Nna $m$ weta ka e rijuo afo, nne debe ka anyi rie echi

A father brings to satisfy immediate hunger but a mother keeps back to ensure the children are not hungry tomorrow).

5. Nne muru umu anaghi eri nri

A mother does not eat

6. Nwata muta iri elu, nne ya amuta ibe akwa

If a child learns to climb, his mother learns to cry (mother's love)

7. Nwata nwere ike were ara nne ya gwue egwu ma aka ya agaghi eru n'amu nna ya

A child can play with its mother's breasts but not with the father's testicles

The importance and role of a mother in Igbo culture is overtly portrayed in the proverbs above. Women are constructed as the 
centre figure in the family and the society in general. She is seen as a giver of care, warmth, and in fact her identity, and life for the family. As a care giver the warmth of her body is medicinal to ailing members of the family including her husband (no.1). Her roles transcend 'mere' child birth, to care giver, nurse, and life line to members of the family. Asimeng-Boahene (2013, p. 129) notes that women not only "bear life, but they nurse , they cherish, they give warmth, they care for life since all human life passes through their bodies"( p. 129). Though stereotypes as seemingly powerless and inferior to men, women bear, nurture, care and raise the culturally constructed powerful and superior members of the society - men. This reflects the woman's liberality in giving and nurturing life to all human including the man.

\section{ii. Women as role models and teachers:}

This is because of a woman's role as an educator, role model and disciplinarian of her family. The following proverbs capture those roles;

8. Nne ewu na-ata agbara nwa ya a na-ele ya anya n' onu

When a mother goat is eating her fodder, the child watches her mouth)

9. Ukwu nne okuko zoro ya anaghi egbu ya

A hen marching of her young one does not kill it

10. O na-adi mma nwata choro ịnu, ya anwuo n'aka nne ya

It is always good for the child that wants to die to die in the hands of the mother)

The educative role of a woman to her child/ children can sometimes be likened to the animal and the young / children.

The woman is also constructed positively in Igbo proverbs as wise especially the elderly women 'nwaanyi agadi'. She is portrayed as a role model, from whom lessons of life and 
experiences are learnt from. Oha (p.91) also captures the wisdom and ability of a woman to exercise her mental prowess in the proverb;

11. Agadi nwaanyi anaghị aka nka n'egwu o maara agba An old woman is never old in the dance she know so well

\section{iii. Women as Resilient:}

She is also portrayed as resilient and dogged. She does not look back when it comes to achieving a set goal or target. ;

12. Kama ihe nwaanyi sinyere n' oku agaghi eghe, nku gwu n' ohịa

Instead of the food being cooked by a woman not being done, let the fire wood in the bush be exhausted/ finish

13. Nne oru oru ma umu rie nri

Mother that works for the children to eat

The positive portrayal of Igbo women in the proverbs discussed above are however undermined by a number of proverbs which on the other hand portray women in negative light as evil, feeble minded, irrational, erratic, wicked and wholly dependent on men for affirmation of their thoughts and deeds. This substantiates the position of feminist linguists on the pejorative and derogatory portrayal of women in patriarchal cultures geared towards alienating and personal debasement of women in a bid to retain dominance as the powerful members of the society. In Oha ( $\mathrm{p}$. 92)'s words, in "sexist Igbo proverbs, women are portrayed as being childish, irresponsible, foolish, weak, unreliable, wicked, dangerous and generally inferior to men. Also, they are suggested as sexual objects". Proverbs that fall under the negative portrayal of women are discussed under the following sub-categories; 


\section{iv. Women as incompetent and dependent on men:}

In traditional Igbo society, males are socialised to see themselves as "indispensible, superior to, and stronger, and more important than females. Females on the other hand, were made to see themselves as appendages of male" (Ozumba 2005 p.2). The proverbs below are reflection of the cultural construction of womanhood. A woman is socialised to believe that she is inferior to man and needs a man to achieve societal reconnection.

\section{Nwaanyị lelie di ya, ike akpoo ya nku}

If a woman disdains her husband, her vulva will dry up

15. Ohu nwaanyi machaa mma, o ga-ara onwe ya?

The beauty of a woman's vagina does not give it license to make love to itself

16. A na-aso nwaanyị oke ikpu anya, o ga-ara onwe ya

Who is shy of a woman with a large vagina? Will it sex itself?

17. Nkita nwanyi zuru na-ata akwa.

A dog trained by a woman eats egg. This portrays the incompetence of a woman in child upbringing.

18. Ewu nwaanyi nwe zuru onwe ya

A goat own by a woman, fends for itself

19. Onye nwe nwaanyi nwe ihe ya

He who owns a woman, owns her possessions

20. Aka ji nwaanyi bu di ya

The hand that holds a woman is her husband

21. Nwaanyi na-amaghị aha di ya ga-ama ya ụbọchị agwọ batara n' ụlọ ha

A woman who does not know the husband's name, will know it the day a snake enters their house) 
Proverb no. 14, 15 and 16 are used to disparage a woman and her inability to satisfy herself especially sexually thereby depending on a man for her satisfaction. No 17 can be viewed from positive and negative perspective. From the positive viewpoint, a woman is seen as a care giver capable of petting/lavishing her love on a child even to the point of spoiling the child. On the other hand, it could be used to refer to a woman as incapable of raising a child singlehandedly without the child getting spoilt. The meaning or interpretation of the proverb depends on its context of use. This validates Nwachukwu-Agbada (2002)'s claim on the role of context in the construction of meaning. The negative construction of no 17 also is applicable to number 18, where reference is made to a goat raised by a woman which is as good as the goat fending for itself.

\section{v. Women and importance of marriage to them:}

22. Mma nwaanyi bu di

The beauty of a woman is her husband

23. Di bu ugwu nwaanyi

Marriage ( husband) is the beauty of a woman

24. Nwaanyi tochaa, a naghi ajuzi onye muru kama a juwazie o bu onye na-alu

A lady having attained maturity, one no longer asks who is the father, but rather who is the husband

25. Nwunye awo sị na di atọk uto, ya jiri nuta nke ya kworo ya n'azu.

The female toad said that husband is so sweet that when she got married, she carried her husband permanently on the back. 
Number 22 and 23 may be used in the same context. It is an instance of saying the same thing in a different way. Numbers 24 and 25 also point to the significance of marriage in Igbo society. The Igbo society places utmost value on marriage and an unmarried female adult is regarded as a social outcast devoid of honour. Sometimes she is stereotyped and called different derogatory names to depict moral laxity, ugly and highhandedness. The value the Igbo society places on marriage has led to many women staying back in abusive relationships for fear of being stigmatised by the church and society. So, to be an unmarried female adult is to be without honour since 'husband/ marriage is the honour/respect of a woman. No 25 also extols the value of marriage to women by drawing analogy with a female frog which carries its male counterpart (its husband) at the back due to the sweetness of marriage / husband to the female.

\section{vi. Women and their appearance:}

26. Omu nkwu dịka nwanyi, o towe o dịka o ga-amapu eluigwe, e meechaa o buru mkpo akịịa

The tender palm tree is like a young woman, when shooting out, it looks as if it will touch the sky, after a while it becomes old and useless

27. Yִdara huru agbogho o daghi, o bu onye ka o ga-adara An apple that sees a beautiful lady and refuses to fall, who will it then fall for)

28. A na-echere ogeri, o na-eche okwa uri ya.

One would be thinking of a woman's good but she would be thinking of her make-up artist. 
A woman is constructed here as placing more value or interest in her appearance more than things that will be of lasting value to her. This is a negative portrayal of a woman and her inability to think right, make right choices as well as ordering her priorities.

\section{vii. Women as sex objects and satirising the woman's body:}

This involves the objectivisation of women and the use of obscene proverbs to refer to woman's body parts, there are reflected as subman' that is used by man to meet his sexual desires. In his words, Oha (p.93) notes that "Woman, the "sexual object," is thus disempowered. She cannot think and act properly: somebody (man) has to guide her and prevent her from destroying herself!" She is constructed as being immature, not knowing her right from left and not capable of discerning good from bad even in things that concern her.

29. A naghi ajụ ajuju otu ebe nwaanyi muru nwa

You do not ask for the availability of the vagina where a woman puts to birth)

30. Di $m$ ju $m$ ji n'ehihie, abali ya ajukwala $m$ oh $u$

If my husband refuse giving me yam in the afternoon, at night let him not ask me access to my vulva

31. O huru ikpu nwanyị na-acho ekua (nke gbajuru aji)

One that sees a woman's vulva and he is looking for one with hairs

32. Ma afo ime enweghi ike ime ikpu ihe, ya ewịa ya aji

If a pregnancy can do nothing to the vulva, it can at least wear off its hairs

\section{viii. Women as contenders of fellow women:}

33. M kaara nwunye dị $m$ na afo na-asa $m$, o sị $m$ puta mgba 
If I tell my co-wife that I have diarrhea, she will ask my hand in a wrestling contest

34. Nwanyi anaghi eji na nwunyedi ya kwere ya ekene nke oma kpowa ya ogo

A woman does not regard her sister-wife as sister-in-law just because she (her husband's other wife) accepted her greeting gracefully

\section{ix. Women as tale bearer:}

35. Nwoke luchaa ogu nwanyi enwere akuko

The man does the fighting, while the woman tells the story

36. Nwanyi abuo kwuru ije, asịi emee ha ato

When two women set out for a walk, gossip becomes their third companion

\section{x. Women as supplanters/selfish :}

Women sometimes are constructed as supplanters capable of disposing their husbands and other members of their societies of their thing subtly. Sometimes they are constructed as using sweet tongue to disposes their husbands of their belongings / valuable or sometimes constructed negatively as selfish folk capable of utilizing manipulative languages to make their husbands act otherwise.

37. Nwaanyi ojoo na-abu ubochị di ya zutaara ya anu, ya akpoo ya deede, ma ubochi o na-azutaghi , o cheetere ya nwoke oma ghaara ilu ya

A bad woman will call the husband deede ( honorific name for elder brother) when he buys meat for her but will remind 
on the day he fails to buy it will remind him of the handsome rich suitor that would have married her.

38. Nwanyi olu oma, di ya adighi ajuru ya nri.

A husband does not reject food cooked by a sweet tongued wife or woman

39. Nwanyị olu oma na-eri di ya

A sweet tongued woman eats her husband

40. Ajo nwanyi bu nka di ya

A bad woman is the aging of the husband

41. Nwanyi bu njo ala

Women are evil of the land

\section{xi. Women as unreliable:}

42. A na-emere nwanyi, o na-emere onye soro ya

43. O jiri nwanyi hiri isi gba aka aju

Any person who uses a woman as a pad in carrying a luggage is carrying the luggage without a pad)

44. Eri ago mere umunwaanyi adighi agba afo onu

Denial of enjoyment is responsible for women not having moustache

This portrays women as capable of denial of any good or favour done to them.

\section{xii. Women as Vulnerable:}

45. Nwanyi makaria di ya n' uzo, ihe cheere di ya ewere ya

If a woman sets off early before her husband, what awaits her husband will befall her.

These proverbs reflect the vulnerability and powerlessness of women. Here a lady reports an evil that was inflicted on her and in a bid to retaliate, she was met by a severer kind of rape. 


\title{
Conclusion
}

A cursory look at the proverbs examined gave insight into two forms of cultural conceptualisation in Igbo society, which is either positive or negative. Under the positive construction, three sub categories were identified while the negative construction we elicited nine categorisation which therefore posits that in spite of the positive cultural conceptualisation, there is overwhelming number of proverbs which portray the woman in negative light as inferior to man, vulnerable and wicked. In Igbo proverbs, which are reflections of the society, women are associated with evil and evil occurrences. She is objectivised and materialised as a sex object, trivialised as senseless and unable to take a decision of her own and voiceless as she depends on her husband or other male members of the family and the society in general to give her voice or validate her opinion. Her voice and identity are submerged into that of the closest male. Men on the hand are portrayed as good, strong, enigmatic and faultless, The age long stereotype is still subtly transmitted in the modern Igbo society through the use of proverbs.

\author{
Ngozi U. Emeka-Nwobia \\ Department of Linguistics and \\ Literary studies, \\ Ebonyi State University, \\ Abakalki \\ \& \\ Roseline I. Ndimele \\ Department of Linguistics and \\ Communication Studies \\ Abia State University, Uturu
}




\section{References}

Alecia Carter. (2018). Women ask fewer questions than men in academic seminars

http://blogs.lse.ac.uk/impactofsocialsciences/2018/01/17/w

omen-ask-fewer-questions-than-men-in-academic-

seminars/. Accessed June, 2018

Amy Hinsley, William J. Sutherland, and Alison Johnston, (2017).

Men ask more questions than women at a scientific conference. PLoS One. 2017; 12(10): e0185534.

https://www.ncbi.nlm.nih.gov/pmc/articles/PMC5643049/.

Accessed June, 2018.

Arendt, Hannah (1970). On Violence. (New York: Harcourt, Brace \& World, Inc., 35.

Arua, Arua Eke ( 1993). "Marital naming in Ohafia Igbo society". Women and Language xv(2) 8-10

Arua, Arua Eke and Yisa K. Yusuf (2010). Sexism and Translation of Igbo proverbs in things fall apart.

Crawford, M. (1997). Talking difference on gender and language. Thousand Oaks, CA: Sage Publications Inc.

Diabah, G. and Amfo, N. (2015): Caring Supporters or Daring Usurpers? Representation of Women in Akan Proverbs. Discourse and Society, Vol 26 (1): 3-28

Dubois, B. L. \& I. Crouch (1975). 'The question of tag questions in women's speech: they don't really use more of them, do they?' Language in Society, 4, 289-94.

Emeka-Nwobia N.U. (2019) Language Endangerment in Nigeria: The Resilience of Igbo Language. In: Brunn S., Kehrein R. (eds) Handbook of the Changing World Language Map. Springer, Cham

DOI https://doi.org/10.1007/978-3-319-73400-2_33-1 
Ethnologue (2018). Igbo: a language of Nigeria. n.a. 2018. SILInternational. oai:ethnologue.com:ibo

Fishman, P. (1980). 'Conversational insecurity'. In D. Cameron (ed.) 1990 The Feminist Critique of Language: A Reader. Pp. 234-241. London: Routledge.

Gay, William C. (1997). "The Reality of Linguistic Violence against Women." in Laura O'Toole and Jessica Schiffman (eds.) Gender Violence: Interdisciplinary Perspectives. (New York: New York University Press. Pp. 467-473.

Greenawalt, Kent. (1995). Fighting Words: Individuals, Communities, and Liberties of Speech. Princeton, N.J.: Princeton University Press.

Holmes, J., \& Wilson, N. (2017). An introduction to sociolinguistics (Fifth edition, Vol. Learning about language). London: Routledge

Jones, D. (1980). 'Gossip: notes on women's oral culture'. In D. Cameron (ed.). The Feminist Critique of Language: A Reader. Pp. 242- 250. London: Routledge.

Kuma Carolyn. "African women and Literature". West African Review. 2 Ogundipe-Leslie, Molara. Recreating ourselves: African women and critical transformation

Lakoff (1973). Language and Woman's Place. In Language in Society. Vol. 2, No. 1 (Apr., 1973), pp. 45-80

Lakoff, R. 1975 Language and Woman's Place. New York: Harper \& Row.

Maltz, D. \& R. Borker 1982 'A cultural approach to male-female miscommunication'. In J. J. Gumpertz (ed.) 1982 Language and Social Identity. Pp. 195-216. Cambridge: Cambridge University Press.

Mizokami, Y. 1995 'Women's Language' as the Ideological Fabrication: A critical assessment of sex difference 
research in English and Japanese sociolinguistics'. M.A. dissertation, University of London.

Mmadike. B.I. 2014. The Igbo Perception of Womanhood: Evidence from Sexist Proverbs. Research on Humanities and Social Sciences

www.iiste.org) Vol.4, No.18, pp.98-104

Mulac, A. 1998. "The Gender-Linked Effect: Do Language Differences Really Make A Difference?" In D. Canary and K. Dindia (eds.) Sex Differences and Similarities in Communication: Critical Essays and Empirical Investigations of Sex and Gender in Interaction. Mahwah, NJ: Lawrence Erlbaum.

Mulac, A., Bradac, J. J., \& Gibbons, P. (2001). Empirical support for the gender-as-culture hypothesis: An intercultural analysis of male/female language differences, Human Communication Research, 27, 121-152

Muller, Michael (1995) Africa in America: Slave Acculturation and Resistance in the American South and the British Caribbean, 1736-183. University of Illinois Press

Nwachukwu-Agbada, J.O.J. 2002. The Igbo proverb. Enugu: John Jacobs Classic Publishers.

Oha, O. 1998. The Semantics of Female Devaluation. African Study Monographs, 19(2): 87-102, October 1998

Poynton, C. 1989. Language and gender: Making the difference. Walton Street, Oxford: Oxford University Press

Ross, S.1981. "How Words Hurt: Attitude, Metaphor, and Oppression" in Mary Vetterling-Braggin (ed.) Sexist Language: A Modern Philosophical Analysis, (Littlefield, Adams and co.

Wardhaugh, Ronald. 2006. An Introduction to Sociolinguistics. Massachusetts: Blackwell. 